\title{
PENGARUH PERLAKUAN VARIASI JENIS GULA TERHADAP TINGKAT KESUKAAN DODOL PEPAYA (Carica vasconcellea)
}

\section{THE EFFECT OF SUGAR VARIATION ON PREFERRENCY OF PAPAYA (Carica vasconcellea) "DODOL"}

\author{
Sukmawati $^{1)}$, Methatias Ayu $\mathbf{M}^{2)}$, Lina Widawati ${ }^{3)}$ \\ 1) Program Studi Teknologi Pangan Fakultas Pertanian UNIVED \\ ${ }^{2)}$ Program Studi Teknologi Pangan Fakultas Pertanian UNIVED \\ ${ }^{3)}$ Program Studi Teknologi Pangan Fakultas Pertanian UNIVED
}

\begin{abstract}
ABSTRAK
Pepaya (Carica vasconcelea) merupakan buah tropis yang memiliki kandungan gizi yang tinggi . Secara umum, buah pepaya matang dikonsumsi langsung, tetapi juga bisa diolah menjadi produk makanan seperti dodol pepaya. Dodol merupakan salah satu produk olahan buah termasuk dalam jenis makanan semin basah yang terdiri dari campuran tepung beras dan gula. Untuk menghasilkan dodol pepaya sesuai dengan kualitas yang diharapkan maka dilakukan penelitian menggunakan beberapa jenis gula dalam pembuatan dodol pepaya. Penelitian ini bertujuan untuk mengetahui tingkat kesukaan panelis terhadap dodol pepaya berdasarkan parameter warna, rasa dan tekstur. Perlakuan yang digunakan dalam penelitian ini adalah kombinasi dari gula, yaitu penambahan gula merah dan gula pasir, gula merah dan gula kelapa, gula kelapa dan gula pasir. Analisis yang digunakan dalam penelitian ini adalah analisis organoleptik. Dari hasil penelitian ini adalah bahwa dri segi parameter warna, dodol pepaya yang paling disukai adalah pengolahan dodol pepaya dengan penambahan gula aren dan gula kelapa . Dari segi parameter rasa, dodol pepaya yang paling disukai adalah pengolahan dodol pepaya dengan penambahan gula merah dan gula pasir . Dari segi parameter tekstur, dodol pepaya yang paling disukai adalah pengolahan dodol pepaya dengan penambahan gula merah dan gula pasir .
\end{abstract}

Kata kunci : Dodol pepaya, Gula, Tingkat kesukaan

\section{ABSTRACT}

Papaya (Carica vasconcelea) is a tropical fruit that has a high nutrient content. In general, ripe papaya fruit is consumed directly, but can also be processed into food products such as papaya "dodol". "Dodol" is one of the processed fruit products are included in this type of semi-moist food consisting of a mixture of rice flour and sugar. To produce papaya "dodol" accordance with the expected quality used some kind of sugar in the making. This study aims to determine the level of papaya "dodol" a panelist to both of the parameters of color, flavor and texture. The treatments used in this study is a combination of sugars, namely the addition of brown sugar and granulated sugar, brown sugar and coconut sugar, coconut and sugar and granulated sugar. The analysis used in this study is the organoleptic analysis. From the results of this research is that in terms of the parameters of color, papaya "dodol" most preferred is the treatment of papaya with the addition of palm sugar and coconut sugar. In terms of taste parameters, papaya"dodol" most preferred is the treatment of papaya with the addition of brown 
sugar and granulated sugar. In terms of texture parameters, papaya "dodol" most preferred is the treatment of papaya with the addition of brown sugar and granulated sugar.

Keywords : Papaya "dodol”, sugar, Preferrency

\section{PENDAHULUAN}

Pepaya (Carica vasconcelea) merupakan tanaman tropis yang bernilai ekonomis tinggi, karena semua bagian dari tanaman ini dapat dimanfaatkan untuk berbagai macam kegunaan seperti olahan untuk sayur, kosmetik dan juga olahan makanan. Buah papaya juga memiliki kandungan gizi yang tinggi teutama pro vitamin A. Buah pepaya masak biasa dikonsumsi secara segar akan tetapi juga dapat diolah menjadi saos, manisan pepaya, dodol pepaya dan sebagainya. Menurut Standar Nasional Indonesia, dodol adalah produk makanan yang dibuat dari tepung beras ketan, santan kelapa dan gula dengan atau tanpa penambahan bahan makanan dan bahan tambahan makanan lain yang diizinkan (SNI, 1992). Tepung beras ketan berfungsi sebagai bahan pengikat dan dapat meningkatkan jumlah kabohidrat dalam dodol buah. Gula dalam pembuatan dodol berfungsi untuk memberikan rasa manis dan kandungan gula yang tinggi dalam dodol dapat meningkatkan umur simpan makanan semi basah ini (Satuhu, 2004).
Dalam pembuatan dodol pepaya, gula berperan penting dalam menentukan mutu dodol pepaya. Gula dalam pembuatan dodol pepaya sangat berperan penting karena sebagai pencipta rasa manis pada dodol, gula juga merupakan bahan pengawet alami pada makanan, tanpa gula dodol mungkin tidak akan banyak diminati oleh konsumen. Gula juga terbagi menjadi beberapa macam yaitu gula aren, gula kelapa dan gula pasir. Penelitian ini bertujuan untuk mengetahui tingkat kesukaan panelis terhadap dodol pepaya dengan kombinasi jenis gula baik dari parameter warna, rasa dan kekenyalan..

\section{METODE PENELITIAN}

\section{Bahan dan Alat}

Bahan yang digunakan dalam penelitian iniadalah buah pepaya gunung yang memiliki tingkat kematangan yang seragam, tepung ketan, santan, gula pasir, gula aren, gula kelapa dan garam. Peralatan yang digunakan dalam penelitian ini adalah baskom, pisau. parutan, wajan, pengaduk kayu, timbangan, kompor gas, keranjang 
plastik, saringan, kuali, plastik pembungkus.

\section{Metode}

Penelitian dilakukan pada pengolahan dodol pepaya dengan melakukan 3 variasi bahan dasar yang berbeda yaitu perlakuan penambahan gula aren dan gula pasir, perlakuan penambahan gula aren dan gula kelapa, perlakuan penambahan gula pasir dan gula kelapa dengan tahapan pembuatan dodol pepaya sebagai berikut :
A. Persiapan Gula Sesuai Perlakuan
Perlakuan penambahan gula aren dan gula pasir ( $1: 1)$
Perlakuan penambahan gula aren dan gula kelapa ( 1:1)
Perlakuan penambahan gula kelapa dan gula pasir ( $1: 1)$
B. Pengolahan dodol pepaya

1. Pencampuran gula sesuai perlakuan dengan santan, tepung ketan, buah papaya yang sudah dihaluskan dan garam.

2. Pemasakan dan diaduk - aduk hingga mengental

3. Setelah didinginkan selama \pm 1 jam sampai adonan dingin.

C. Uji organoleptik

\section{HASIL DAN PEMBAHASAN \\ Oganoleptik Warna}

Warna penting bagi banyak makanan, baik bagi makanan yang tidak diproses maupun bagi yang dimanufaktur. Bersama-sama dengan bau, rasa, dan tekstur warna memegang peranan penting dalam penerimaan makanan (Deman, 1997). Suatu bahan makanan yang dinilai bergizi, enak, dan teksturnya sangat baik tidak akan dimakan apabila memiliki warna yang tidak sedap dipandang atau memberi kesan menyimpang dari warna yang seharusnya (Winarno, 1997). Rerata kesukaan panelis terhadap warna dodol pepaya dengan perlakuan kombinasi gula berkisar antara 1,47 (suka) sampai 3,73 (tidak suka). Hasil analisis warna dodol pepaya dapat dilihat pada Tabel 1 dan Tabel 2.

Tabel 1. Nilai Rerata Kesukaan Warna Dodol Pepaya

\begin{tabular}{ll}
\hline Variasi Perlakuan & Warna \\
\hline Perlakuan Gula Aren dan Gula Pasir & 2,00 \\
Perlakuan Gula Pasir dan Gula Kelapa & 3,73 \\
Perlakuan Gula Aren dan Gula Kelapa & 1,47 \\
\hline = Sangat suka, 2 = Suka, 3 = Agak suka, 4 = Tidak suka, 5 = Sangat tidak suka
\end{tabular}


Tabel 2. Anova Warna

\begin{tabular}{cccccc}
\hline SV & DB & JK & MS & F. Hitung & F. Tabel \\
\hline Penelis & 79 & 325,796 & 4,124 & 0,22 & 1,36 \\
Perlakuan & 2 & 955,265 & 477,632 & 25,92 & 3,06 \\
Error & 158 & 2894,22 & 18,427 & & \\
Total & 239 & & & \\
\hline Ket $:$ F Hit $<$ F Tab & Tidak berbeda nyata \\
F Hit $>$ F Tab & Beda nyata
\end{tabular}

Dari Tabel 2 dapat diketahui dari segi panelis tidak berbeda nyata yang hal ini berarti dari kedelapan puluh panelis menilai warna dodol pepaya tidak berbeda. Dai segi perlakuan penggunaan kombinasi gula, dai ketiga perlakuan memberikan perbedan yang nyata. Dari Tabel 1 juga dapat dilihat bahwa dodol pepaya yang paling disukai yaitu dodol pepaya dengan perlakuan penambahan gula aren dan gula kelapa dengan rerata penilaian pada skala suka. Hal tersebut dikarenakan dodol yang dihasilkan memiliki warna yang khas dan menarik dibandingkan dengan warna yang dihasilkan oleh dodol dengan perlakuan penggunaan gula yang lain. Warna yang dimiliki dodol pepaya dengan penambahan gula aren dan gula kelapa adalah warna merah kecoklatan hal tersebut karena pengaruh dari warna khas gula aren dan gula kelapa itu sendiri. Sedangkan untuk warna dodol pepaya pada perlakuan penambahan gula aren dan gula pasir juga disukai oleh penelis warna yang dihasilkan yaitu warna coklat yang lebih tua, sedangkan yang kurang begitu disukai oleh penelis adalah perlakuan penambahan gula pasir dan gula kelapa karena warna yang dihasilkan lebih pucat yaitu warna coklat kekuningan warna yang kurang menarik karena seperti dodol yang belum masak. Menurut Purwanto, dkk (2013), warna dodol rumput laut yang dipengaruhi oleh warna coklat yang terbentuk. Reaksi pencoklatan juga dipengaruhi oleh nilai aw. Di dalam bahan pangan, reaksi pencoklatan non enzimatis akan meningkat bila aw dinaikkan dan akan mencapai maksimum pada batas nilai aw bahan pangan semi basah.

\section{Organoleptik Rasa}

Analisis organoleptik dari segi rasa menunjukkan tingkat kesukaan panelis terhadap rasa pedas, manis, asam dan gurih yang dihasilkan. Rerata kesukaan panelis terhadap rasa dodol pepaya akibat perlakuan kombinasi gula berkisar antara 1,57 (suka) sampai 3,00 (agak suka). Hasil analisis rasa dodol pepaya dapat dilihat pada Tabel 3 dan Tabel 4. 
Tabel 3. Rerata Kesukaan Rasa Dodol Pepaya

\begin{tabular}{cc}
\hline Variasi Perlakuan & Rasa \\
\hline Perlakuan Gula Aren dan Gula Pasir & 1,57 \\
Perlakuan Gula Pasir dan Gula Kelapa & 3,00 \\
Perlakuan Gula Aren dan Gula Kelapa & 2,00 \\
\hline = Sangat suka, 2 = Suka, 3 = Agak suka, 4 = Tidak suka, 5 = Sangat tidak suka
\end{tabular}

Tabel 4. Anova Rasa

\begin{tabular}{cccccc}
\hline SV & DB & JK & MS & F. Hitung & F. Tabel \\
\hline Penelis & 79 & 788,6 & 0,98 & 0,87 & 1,36 \\
Perlakuan & 2 & 1240,635 & 620,31 & 54,17 & 3,06 \\
Error & 158 & 1809,235 & 11,45 & & \\
Total & 239 & & & \\
\hline Ket $\quad$ F Hit $<$ F Tab & $=$ Tidak berbeda nyata \\
F Hit $>$ F Tab & $=$ Berbeda nyata
\end{tabular}

Berdasarkan rerata tingkat kesukaan terhadap rasa dodol pepaya diketahui rasa dodol pepaya pada 3 variasi perlakuan yang berbeda maka didapat hasil adalah perlakuan penambahan gula aren dan gula pasir dengan nilai rerata 1,57 termasuk kedalam katagori nilai yang disukai dan selanjutnya pada konsentrasi perlakuan penambahan gula pasir dan gula kelapa dengan nilai rerata 3,00 termasuk kedalam katagori nilai agak suka hal ini berarti tidak begitu disukai, perlakuan penambahan gula aren dan gula kelapa dengan nilai rerata 2 termasuk kedalam katagori suka. Akan tetapi dari ketiga perlakuan tersebut dilihat dari nilai reratanya yang paling disukai adalah perlakuan penambahan gula aren dan gula pasir karena rasa yang dihasilkan perlakuan tersebut menghasilkan rasa manis yang pas, sehingga disukai oleh konsumen. Pada perlakuan penambahan gula aren dan gula kelapa yang juga disukai oleh beberapa penelis yang mungkin bukan penggemar rasa manis karena rasa dodol pepaya yang dihasilkan memiliki rasa manis yang tidak terlalu kuat hal ini karena dipengaruhi oleh kadar sukrosa yang dikandung oleh gula aren sebesar $84,31 \%$ dan gula kelapa $75,63 \%$ yang cukup berbeda dengan kandungan sukrosa yang dikandung oleh gula pasir yang lebih besar $97,10 \%$.

Sedangkan untuk perlakuan penambahan gula pasir dan gula kelapa rasa yang dihasilkan sangat berbeda dengan perlakuan yang lain, rasa yang dihasilkan tidak terlalu manis akan tetapi lebih dominan rasa pepaya gunung yang memiliki rasa asam dan berbau tidak enak, sehingga sebagian penelis kurang 
begitu menyukai hasil dodol pepaya dari perlakuan penambahan gula pasir dan gula kelapa tersebut.

Tabel anova rasa diatas menunjukan penilaian antara panelis tidak berbeda nyata, sedangkan perlakuan dari tiga sampel berbeda nyata. Hal ini berarti perlakuan yang diberikan menghasilkan pengaruh yang nyata pada parameter rasa karena rasa yang dihasilkan berbeda nyata. Menurut Winarno (1991) dalam Marpaung (2001), bahwa rasa dodol rumput laut yang timbul didominasi oleh rasa karena karamel yang timbul karena adanya kandungan gula dan adanya pemanasan yang suhunya melampaui titik leburnya.

\section{Tekstur}

Untuk dapat merasakan tekstur suatu produk digunakan indera peraba. Indera peraba yang biasa digunakan untuk makanan biasanya di dalam mulut dengan menggunakan lidah dan bagianbagian di dalam mulut, dapat juga dengan menggunakan tangan sehingga dapat merasakan tekstur suatu produk makanan. Tekstur juga menjadi salah satu faktor penentu kualitas yang perlu diperhatikan. Analisis organoleptik dari segi tekstur menunjukkan tingkat kesukaan panelis terhadap tekstur sambal hijau tempoyak. Rerata kesukaan panelis terhadap tekstur dodol pepaya akibat perlakuan kombinasi jenis gula berkisar antara 1,55 (suka) sampai 3,16 (agak suka). Hasil analisis tekstur dodol pepaya dapat dilihat pada Tabel 5 dan Tabel 6 .

Tabel 5. Nilai rerata kesukaan kekenyalan dodol pepaya Variasi Perlakuan Kekenyalan

Perlakuan Gula Aren dan Gula Pasir $\quad$ 1,55

Perlakuan Gula Pasir dan Gula Kelapa $\quad 3,16$

Perlakuan Gula Aren dan Gula Kelapa $\quad 2,20$

Skala penilaian : $1=$ Sangat suka, $2=$ Suka, $3=$ Agak suka, $4=$ Tidak suka, $5=$ Sangat tidak suka

\subsubsection{Tabel Anova Kekenyalan}

\begin{tabular}{cccccc}
\hline SV & DB & JK & MS & F. Hitung & F. Tabel \\
\hline Penelis & 79 & 932,33 & 11,80 & 0,89 & 1,36 \\
Perlakuan & 2 & 1364,93 & 682,24 & 51,64 & 3,06 \\
Error & 158 & 2088,26 & 13,21 & & \\
Total & 239 & & & &
\end{tabular}

$\begin{aligned} \text { Ket }: \text { F Hit }<\text { F Tabel } & \longrightarrow \text { Tidak berbeda nyata } \\ \text { F Hit }>\text { F Tabel } & \longrightarrow \text { Berbeda nyata }\end{aligned}$

F Hit $>$ F Tabel $\longrightarrow$ Berbeda nyata 
Berdasarkan rerata tingkat kesukaan penelis terhadap tekstur dodol pepaya diketahui bahwa tekstur dodol pepaya dari tiga variasi perlakuan yang berbeda tersebut maka hasilnya adalah perlakuan penambahan gula aren dan gula pasir dengan nilai rerata 1,55 termasuk kedalam katagori nilai yang disukai dan selanjutnya pada konsentrasi perlakuan penambahan gula pasir dan gula kelapa nilai rerata 3,16 termasuk kedalam katagori nilai agak suka, perlakuan penambahan gula aren dan gula kelapa dengan nilai rerata 2,20 termasuk kedalam kategori disukai.

Penambahan gula memiliki pengaruh terhadap rasa dan tekstur makanan karena gula berfungsi sebagai sumber nutrisi dalam bahan makanan, gula juga sebagai pembentuk tekstur dan bentuk flavour melalui reaksi pencoklatan. Peristiwa pencoklatan non enzimatis pada senyawa gula adalah karamelisasi. Karena adanya pemasakan gula pada dodol pepaya menimbulkan proses karamelisasi sehingga mempengaruhi perubahan tekstur pada dodol papaya, hal ini ditunjukan dari kekenyalan yang dihasilkan.

Berdasarkan hasil uji organoleptik yang dilakukan diketahui tekstur dodol pepaya yang paling disukai penelis adalah perlakuan penambahan gula aren dan gula pasir, hal tersebut dikarenakan dodol yang dihasilkan oleh kedua perlakuan tersebut hampir sama, dengan tekstur atau tingkat kekenyalan yang disukai konsumen. Sedangkan perlakuan penambahan gula pasir dan gula kelapa memiliki tekstur yang tidak begitu kenyal dan hasilnya lengket, hal tersebut dipengaruhi oleh kandungan sukrosa pada gula aren dan gula kelapa yang rendah sedangkan kadar airnya tinggi dibandingkan dengan gula pasir. Oleh sebab itu penelis kurang menyukai tekstur atau tingkat kekenyalannya.

Berdasarkan tabel anova tekstur diatas dapat diketahui antara panelis tidak berbeda nyata, sedangkan perlakuan dari tiga sampel berbeda nyata. Dan hal ini berarti perlakuan yang diberikan menghasilkan pengaruh yang nyata pada parameter tekstur. Menurut Purnomo (1995), umumnya konsumen menyukai makanan yang mempunyai aw yang tinggi. Alasannya karena konsumen menyukai bahan pangan yang agak basah serta mudah dikunyah. Jadi kebasahan, empuk, mudah dikunyah, merupakan faktor tekstur yang dikehendaki. Tekstur yang keras pada dodol rumput laut disebabkan proses pengeringan dimana terjadi proses penarikan air dari bahan (Winarno, 1992). Selain pengeringan, tekstur dodol pepaya juga dipengaruhi oleh jenis rumput laut yang digunakan. 


\section{SIMPULAN}

Berdasarkan hasil penelitian tentang pengaruh perlakuan penggunaan gula terhadap tingkat kesukaan dodol pepaya dapat disimpulkan bahwa :

1. Untuk parameter warna, penelis sangat menyukai sampel dengan perlakuan penambahan gula aren dan gula kelapa, karena warna yang dihasilkan tidak terlalu gelap dan menarik. Ditunjukan dari nilai 1,47 yaitu sangat suka.

2. Untuk parameter rasa, penelis lebih menyukai rasa yang dihasilkan dari perlakuan penambahan gula aren dan gula pasir, karena memiliki rasa manis yang pas tidak membuat bosan bagi yang memakannya. Hal ini ditunjukan dari nilai 1,57 yaitu sangat suka.

3. Untuk parameter tekstur, penelis menyukai dodol yang dihasilkan perlakuan penambahan gula aren dan gula pasir hal ini ditunjukan dari nilai perlakuan gula pasir dan gula aren dengan nilai 1,55 yang menunjukan skala penilaian suka.

\section{DAFTAR PUSTAKA}

Marpaung, P. 2001. Pengaruh Konsentrasi Gula Pasir Terhadap Mutu Dodol Rumput Laut. Skripsi. Program Studi Teknologi Hasil Perikanan. FPIK-IPB. Bogor.

Punomo, H. 1995. Aktivitas Air dan Peranannya dalam Pengawetan Pangan.UI Press. Jakarta

Purwanto, Rachmawati Oktavi, Argo, B.D, dan Hermanto M.B. 2013. Pengaruh Komposisi Sirup Glukosa dan Variasi Suhu Pengeringan terhadap Sifat Fisiko-Kimia dan Inderawi Dodol Rumput Laut (Eucheuma spinosium). Jurnal Bioproses Komoditas Tropis. Vol 1. No. 1

Satuhu, S dan Sunarmani, 2004. Membuat Aneka Dodol Buah. Penebar Swadaya, Jakarta

SNI, 1992. Dodol. SNI 01-2986-1992. Pusat Standarisasi Industri. Departemen perindustrian, Jakarta

Winarno, F.G.1992. Kimia Pangan dan Gizi. PT Gramedia. Jakarta

Winarno, F.G. 1997. Kimia Pangan dan Gizi. PT. Gramedia, Jakarta 